\title{
Working Women
}

\author{
Michelle Tracy
}

\begin{abstract}
Femmes au travail
Lorsqu" "elle" appelle "tu" de son travail, "elle" utilise le "vous". "Tu" la taquine à propos de ces formalités, lui décrit le point de vue qu'elle a sur ses cuisses lorsque ses genoux pointent vers le plafond... Les hommes du bureau où travaille "elle" ne connaissent pas "tu"; ils croient qu" elle" est célibataire. À travers ce jeu sur les pronoms personnels, cette juxtaposition de perspectives (sur "elle"), "Femmes au travail" met en lumière l'impossiblité, pour le couple lesbien, de vivre une intimité au quotidien.
\end{abstract}

She calls you "vous" over the phone. You picture her sitting at her desk at work men standing around She is the single woman to them who always has other plans never takes them up on their invitations. She calls you "vous" You tease her describe the way her thigh looks turned up towards you and the sheet peeled back She replies "Vous allez-bien, j'espère?"

You picture her Face at the phone Her workmates in a peripheral vision her lips forming "Vous".

You can't meet her at five, a bunch of flowers in your arms kiss her on the mouth say lets go out to dinner I know a place on St-Denis I'll pay or even, perhaps most of all She won't be able to take time off for your mother's funeral. 